\title{
Fibrin Induces Release of von Willebrand Factor from Endothelial Cells
}

\author{
Julie A. Ribes, Charles W. Francis, and Denisa D. Wagner \\ Hematology Unit, Department of Medicine, University of Rochester School of Medicine and Dentistry, Rochester, New York 14642
}

\begin{abstract}
Addition of fibrinogen to human umbilical vein endothelial cells in culture resulted in release of von Willebrand factor (vWf) from Weibel-Palade bodies that was temporally related to formation of fibrin in the medium. Whereas no release occurred before gelation, the formation of fibrin was associated with disappearance of Weibel-Palade bodies and development of extracellular patches of immunofluorescence typical of $\mathrm{vWf}$ release. Release also occurred within $10 \mathrm{~min}$ of exposure to preformed fibrin but did not occur after exposure to washed red cells, clot liquor, or structurally different fibrin prepared with reptilase. Metabolically labeled vWf was immunopurified from the medium after release by fibrin and shown to consist of highly processed protein lacking pro-vWf subunits. The contribution of residual thrombin to release stimulated by fibrin was minimized by preparing fibrin clots with nonstimulatory concentrations of thrombin and by inhibiting residual thrombin with hirudin or heating. We conclude that fibrin formed at sites of vessel injury may function as a physiologic secretagogue for endothelial cells causing rapid release of stored $\mathrm{vWf}$.
\end{abstract}

\section{Introduction}

Injury to a blood vessel, which disrupts the endothelial cell lining, results in rapid adherence of platelets to the exposed subendothelium mediated by von Willebrand factor $(\mathrm{vWf})^{1}(1,2)$. Both fibrinogen $(3,4)$ and $v W f(5-7)$ may support the plateletplatelet interactions required to form a larger platelet aggregate, which is then stabilized by fibrin formed after concurrent activation of the coagulation system. The importance of $v W f$ in the hemostatic process is reflected by the occurrence of a bleeding disorder, von Willebrand's disease, due to deficient or defective $\mathrm{vWf}(8)$. The vWf required for hemostasis is found in the subendothelium (9), plasma, platelet $\alpha$ granules $(10,11)$, and endothelial cells, where it is both synthesized (12) and stored (13, 14). Endothelial cell storage is in specific rod-shaped organelles called Weibel-Palade bodies (13), from which release may be stimulated in vitro by the ionophore A23187, phorbol myristate acetate, or thrombin $(15,16)$. Also, endothelial cell release may account for the two to threefold increase in plasma $\mathrm{vWf}$ that occurs rapidly after administration of the vasopressin analog 1desamino-8- $d$-arginine vasopressin (17). vWf is structurally het-

Reprint requests should be addressed to Dr. Wagner, Hematology Unit, Box 610, University of Rochester Medical Center, 601 Elmwood Avenue, Rochester, NY 14642.

Received for publication 11 July 1986.

1. Abbreviation used in this paper: vWf, von Willebrand factor.

J. Clin. Invest.

(c) The American Society for Clinical Investigation, Inc.

0021-9738/87/01/0117/07 \$1.00

Volume 79, January $1987,117-123$ erogeneous and can be separated by sodium dodecyl sulfate (SDS) electrophoresis into a series of disulfide-bonded multimers with molecular masses from 500,000 to as high as $20,000,000$ D (8). In cultured endothelial cells, most constitutively secreted molecules are dimeric and contain both precursor (pro-vWf) and processed subunits (18). In contrast, the vWf released from Weibel-Palade bodies after stimulation consists of only the largest multimers of mature subunits (19). The large multimers are more active in platelet-binding assays (8) and their specific absence results in type IIA von Willebrand disease (20).

The initial hemostatic response to vascular injury requires vWf-mediated platelet adhesion and aggregation, and, therefore, the release of high molecular mass vWf multimers from endothelial cells could facilitate formation of a hemostatic plug. Because endothelial cells at the site of vessel injury are in contact with the locally formed fibrin, we have investigated whether fibrin could induce release of $\mathrm{vWf}$ from endothelial cells. Our results demonstrate that fibrin exposure does cause rapid release of $\mathrm{vWf}$ from Weibel-Palade bodies and that fibrin, therefore, could act as a physiologic secretagogue for human endothelial cells.

\section{Methods}

Cell culture. Human umbilical vein endothelial cells were isolated and cultured by a modification of the methods described by Gimbrone and colleagues $(13,21)$. Cells obtained from 5 in of umbilical cord were plated in a single flask or 40-mm Petri dish containing flame-sterilized cover slips. All cells were primary cultures grown in McCoy's 5A medium (Flow Laboratories, Inc., McLean, VA) containing 20\% fetal bovine serum (HyClone Laboratories, Logan, UT). Cells were labeled with $30 \mu \mathrm{Ci} / \mathrm{ml}$ of $\left[{ }^{35} \mathrm{~S}\right]$ methionine (Amersham Corp., Arlington Heights, IL) for $3 \mathrm{~d}$ after they had reached $80-90 \%$ confluency.

Cell staining. Cells grown on coverslips were fixed in Dulbecco's phosphate-buffered saline ( $\mathrm{pH} \mathrm{7)}$ containing $3.7 \%$ formaldehyde and permeabilized when desired with $0.5 \%$ Triton X-100 in the same buffer. Indirect immunofluorescent staining of endothelial cells for $\mathrm{vWf}$ followed the procedure described previously (13). The primary antibody, rabbit anti-human vWf, was prepared as described $(13,22)$ and the secondary antibody was goat anti-rabbit IgG conjugated with fluorescein isothiocyanate (Miles-Yeda, Elkhart, IN). To quantitate $\mathrm{vWf}$ release, a minimum of 100 stained cells were examined for each experimental point. Those cells containing Weibel-Palade bodies with no patches of surface $\mathbf{v W f}$ staining were counted as nonreleased. The presence of patches of $\mathrm{vWf}$ on the cell surface was indicative of release, regardless of the WeibelPalade content. The rare cells with neither Weibel-Palade bodies nor patches of surface vWf were not counted.

Clot preparation. Lyophilized human fibrinogen (grade L; Helena Laboratories, Beaumont, TX) was dissolved in distilled water to a concentration of $20 \mathrm{mg} / \mathrm{ml}$ and dialyzed against Hanks' buffer. The fibrinogen concentration was determined by measurement of optical density at 280 $\mathrm{nm}$ using an extinction coefficient of 15.1 (23). The fibrinogen was diluted to $1.9 \mathrm{mg} / \mathrm{ml}$ in Hanks' buffer, and clots were prepared from $0.7 \mathrm{ml}$ by adding calcium chloride (160 $\mathrm{nM}$ final concentration) and human thrombin (final concentration $1 \times 10^{-3}-4.2 \mathrm{U} / \mathrm{ml}$ ) (Calbiochem-Behring Corp., LaJolla, CA) or reptilase (venom of Bathrops atrox) (Wellcome Reagent Ltd., Beckenham, England) to a final concentration of $1.1 \mathrm{U} /$ $\mathrm{ml}$. The clots were incubated at $25^{\circ} \mathrm{C}$ in a moist chamber for $6-18 \mathrm{~h}$, after which they were incubated for $18 \mathrm{~h}$ in $100 \mathrm{ml}$ of McCoy's medium 
with three changes. Clot liquor was obtained by expressing the fluid from unwashed clots followed by centrifugation at $2300 \mathrm{~g}$ for $10 \mathrm{~min}$ at $27^{\circ} \mathrm{C}$ to remove residual particulate fibrin.

Thrombin assay. Thrombin in solution was assayed using the chromogenic substrate H-D-phenylanlanyl-L-pipecolyl-L-arginine-p-nitroanilide (24) as recommended by the manufacturer (Kabi AB, Stockholm) using the initial rate method. To determine the thrombin content of fibrin clots, the clot and substrate were incubated at $25^{\circ} \mathrm{C}$ with agitation and aliquots of the fluid removed at intervals for measurement of optical density at $405 \mathrm{~nm}$. Concentrations were expressed as units of thrombin per clot, each of which had a volume of $0.3 \mathrm{ml}$.

Purification of metabolically labeled $v W f$. Radiolabeled endothelial cells were chased for $6 \mathrm{~h}$ with unlabeled medium and then washed three times with Hanks' buffer. Cells were then incubated in medium or medium plus $0.1 \%$ dimethylsulfoxide, which was removed after $10 \mathrm{~min}$ for purification of constitutively secreted vWf. The cells were then submitted for 10 min to medium containing $10 \mu \mathrm{M} \mathrm{A23187}$ and $0.1 \%$ dimethylsulfoxide or overlaid with a fibrin clot in medium, after which the medium was removed. Immunopurification of $\mathrm{vWf}$ was performed as described by Wagner and Marder (18) using rabbit anti-human vWf antiserum (Calbiochem-Behring Corp., LaJolla, CA) preincubated with $40 \mu \mathrm{g}$ of protein A Sepharose (Pharmacia Fine Chemicals, Piscataway, NJ).

Electrophoresis. Immunopurified vWf was electrophoresed after reduction on SDS 5\% polyacrylamide gels (25) followed by autoradiography. The amount of protein in individual bands was determined by densitometric scanning (Quick Scan Jr., TLC; Helena Laboratories, Beaumont, TX). Fibrin clots were dissolved to a final concentration of $2.8 \mathrm{mg} / \mathrm{ml}$ in $0.05 \mathrm{M}$ phosphate buffer ( $\mathrm{pH} \mathrm{7)}$ containing $10 \mathrm{M}$ urea, $0.5 \%$ SDS, $0.7 \%$ ethylenediamine tetraacetate, and $5 \% \beta$-mercaptoethanol, electrophoresed in 7\% gels (26); and stained with Coomassie Blue (27).

Blood and purified plasma proteins. After obtaining consent, unanticoagulated whole blood was obtained from healthy volunteers by venipuncture. To obtain red blood cells, $1 \mathrm{ml}$ of whole blood was diluted in $15 \mathrm{ml}$ of Hanks' buffer and centrifuged at $2300 \mathrm{~g}$ for $10 \mathrm{~min}$ at $25^{\circ} \mathrm{C}$. The supernatant was discarded and the washing repeated six times. Purified Factor XIII (Behringwerke A. G., Marburg, FRG) was dissolved in water to a concentration of $1 \mathrm{U} / \mathrm{ml}$ and activated for 30 min with 1 $\mathrm{U} / \mathrm{ml}$ thrombin in $10 \mathrm{mM} \mathrm{CaCl}_{2}$ at $37^{\circ} \mathrm{C}$, and the thrombin inhibited with a 10-fold excess of hirudin. Purified tissue plasminogen activator was a gift from Desire Collen (Leuven, Belgium).

\section{Results}

Adding fibrinogen to cultures of human umbilical vein endothelial cells resulted in the slow formation of fibrin clot over the cells. Coverslips were removed and cells stained for vWf using indirect immunofluorescence with and without permeabilization before clot formation ( $10 \mathrm{~min}$ ) and after the cells became covered with clot $(3 \mathrm{~h})$. Control cells to which no fibrinogen was added were processed in parallel. Cells exposed to fibrinogen for 10 min were indistinguishable from controls with $\mathrm{vWf}$ in the perinuclear region (endoplasmic reticulum and Golgi apparatus) and in Weibel-Palade bodies (Fig. 1, $a$ and $b$ ) and little vWf was associated with the external cell surface (Fig. 1, $d$ and $e$ ). Only $12 \%$ of cells at this time showed any release, which was comparable to that in control cultures. In contrast, at $3 \mathrm{~h}$ (after clot formation) $90 \%$ of cells had lost their Weibel-Palade bodies (Fig. $1 \mathrm{c}$ ) and showed irregular patches of surface staining (Fig. 1, $c$ and $f$ ). Formation of fibrin over the cells was not necessary for release, because fibrin clots prepared separately and transferred onto the cells caused release within $10 \mathrm{~min}$ (see below). Cells in the same dish but not directly underlying the fibrin clot showed no release, which suggested that cell-fibrin contact and not a diffusable substance was necessary for release.

A possible explanation for these results is that the formation of fibrin potentiated the effects of thrombin present in the culture medium at concentrations insufficient to cause release by itself. Therefore, the effects of thrombin and thrombin inhibitors were examined in the system. Thrombin at concentrations from 1 $\times 10^{-4}$ to $1.2 \mathrm{U} / \mathrm{ml}$ in culture medium was added to endothelial cells and the proportion of cells showing any vWf release at 10 min determined (Fig. 2). No significant release occurred at concentrations of $5 \times 10^{-3} \mathrm{U} / \mathrm{ml}$ and below, while at higher concentrations progressively more release was seen up to a concentration of $0.1 \mathrm{U} / \mathrm{ml}$, which caused maximum release.

To minimize their thrombin content, fibrin clots were prepared from fibrinogen using a thrombin concentration of 5 $\times 10^{-3} \mathrm{U} / \mathrm{ml}$, the minimum concentration required for adequate clotting. When placed on cultured endothelial cells in culture medium, these clots stimulated release of vWf within $10 \mathrm{~min}$ (Fig. $3 b$, Table I). To further reduce the effect of thrombin, clots made in the same way were incubated in $0.25 \mathrm{U} / \mathrm{ml}$ hirudin, a thrombin inhibitor, and hirudin was also included at the same concentration in the culture medium to which the preformed clots were added. Although the thrombin content of the clots after hirudin incubation had decreased by $73 \%$, from $1.5 \times 10^{-3}$ to $4 \times 10^{-4} \mathrm{U}$, they still stimulated complete release of $\mathrm{vWf}$ within $10 \mathrm{~min}$. (Fig. $3 e$, Table I). Hirudin by itself in the culture medium at $0.25 \mathrm{U} / \mathrm{ml}$ had no effect on vWf release (Fig. $3 d$, Table I), but this concentration was sufficient to completely inhibit release stimulated by $0.1 \mathrm{U} / \mathrm{ml}$ of thrombin (Fig. $3 f$, Table I).

Heat denaturation was also used to inactivate thrombin. Thrombin in solution showed a progressive temperature-dependent decrease in activity after incubation at temperatures above $37^{\circ} \mathrm{C}$, with no residual activity by chromogenic assay at temperatures of $70^{\circ} \mathrm{C}$ or above (Fig. 4 a). The decrease in chromogenic activity was paralleled by a decrease in the ability of the thrombin to stimulate $\mathrm{vWf}$ release from endothelial cells (Fig. $4 \mathrm{~b}$ ). On the other hand, heated fibrin clots showed no decrease in ability to stimulate $\mathrm{vWf}$ release from endothelial cells despite incubation at temperatures of up to $100^{\circ} \mathrm{C}$ for $2 \mathrm{~h}$ (Fig. 4 b). The inability of hirudin or heat denaturation to reduce the capacity of fibrin clots to stimulate $\mathrm{vWf}$ release indicated that thrombin played little or no role in the process.

After a 10-min exposure of endothelial cells to fibrin, the effect on vWf storage was reversible with slow reappearance of Weibel-Palade bodies and disappearance of surface patches of vWf. Immediately after removal of a preformed clot only $4 \%$ of cells showed any Weibel-Palade bodies, but this increased to $33 \%$ by $2 \mathrm{~h}$ and $92 \%$ at $8 \mathrm{~h}$. In contrast, when fibrin remained over the cells for $3 \mathrm{~h}$, no reappearance of Weibel-Palade bodies was seen. The cell surface vWf patches, present in $96 \%$ of cells at the time of fibrin removal, had not decreased by $2 \mathrm{~h}$ and were still present on $40 \%$ of cells at $8 \mathrm{~h}$. By $24 \mathrm{~h}$ after fibrin removal, the cells were comparable to controls in both content of WeibelPalade bodies and absence of surface staining.

The subunit composition of $\mathrm{vWf}$ released by fibrin clots was compared with that of vWf released by the ionophore A23187 and that secreted without stimulation from the endothelial cells. For this purpose endothelial cells were metabolically labeled for $3 \mathrm{~d}$ with $\left[{ }^{35} \mathrm{~S}\right]$ methionine, then chased for $6 \mathrm{~h}$ in unlabeled culture medium, after which the cells were treated for $10 \mathrm{~min}$ with A23187 or fibrin. Control cells were handled in parallel in the absence of a secretagogue. vWf secreted constitutively during the 3-d labeling period and the 10-min experimental period was immunopurified and analyzed by SDS polyacrylamide gel elec- 


\section{Control}
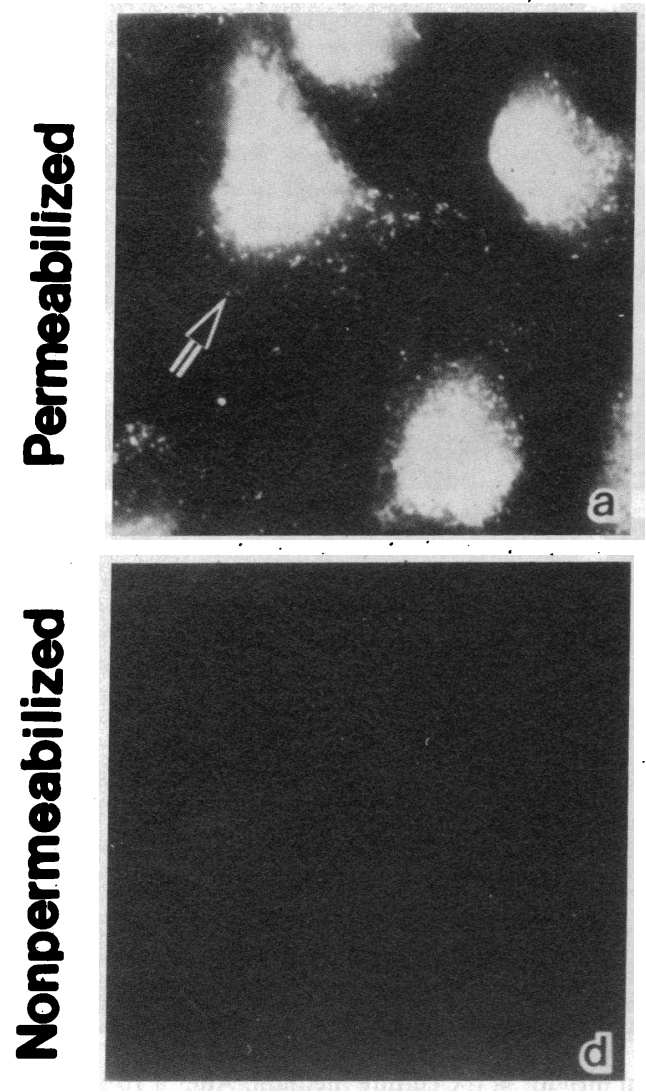

Figure 1. Immunofluorescent localization of $\mathrm{vWf}$ in endothelial cells before and after formation of a fibtin clot in the medium. Human umbilical vein endothelial cells were grown to $70 \%$ confluency, and fibrinogen was added to a final concentration of $0.35 \mathrm{mg} / \mathrm{ml}$. The cells were fixed and stained with anti-vWf antiserum with $(a-c)$ and without $(d-f)$ permeabilization. ( $a$ and $d)$ Untreated control cells. ( $b$ and

trophoresis after reduction. Similar to vWf released by A23187, the protein released by fibrin did not contain pro-vWf subunits found in the constitutively secreted molecules (Fig. 5). In addition, the releasate produced by fibrin contained a vWf fragment of approximately $M_{\mathrm{r}} 180,000$ that was not seen in A23187 releasates (Fig. 5). This fragment comprised $\sim 30 \%$ of the total

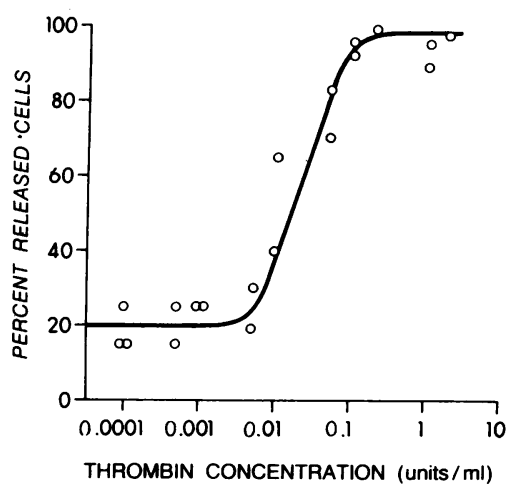

Figure 2. Thrombin-induced release of $\mathbf{v W f}$ from endothelial cells. Endothelial cells were incubated for $10 \mathrm{~min}$ in medium containing the indicated concentration of thrombin. The cells were then fixed, permeabilized, and stained for vWf by indirect immunofluorescence and the percentage of cells showing patches of released $v W f$ determined.

\section{+ Fibrinogen}

$10 \mathrm{~min}$

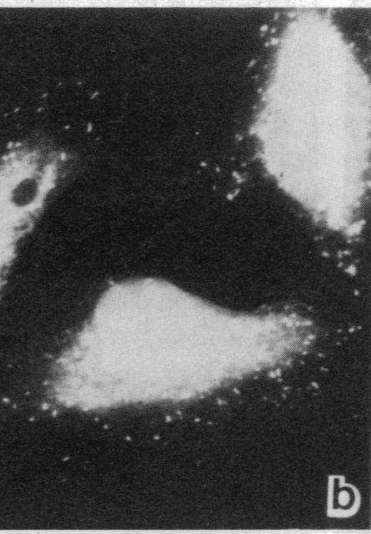

b

e

\section{$3 \mathbf{h}$}
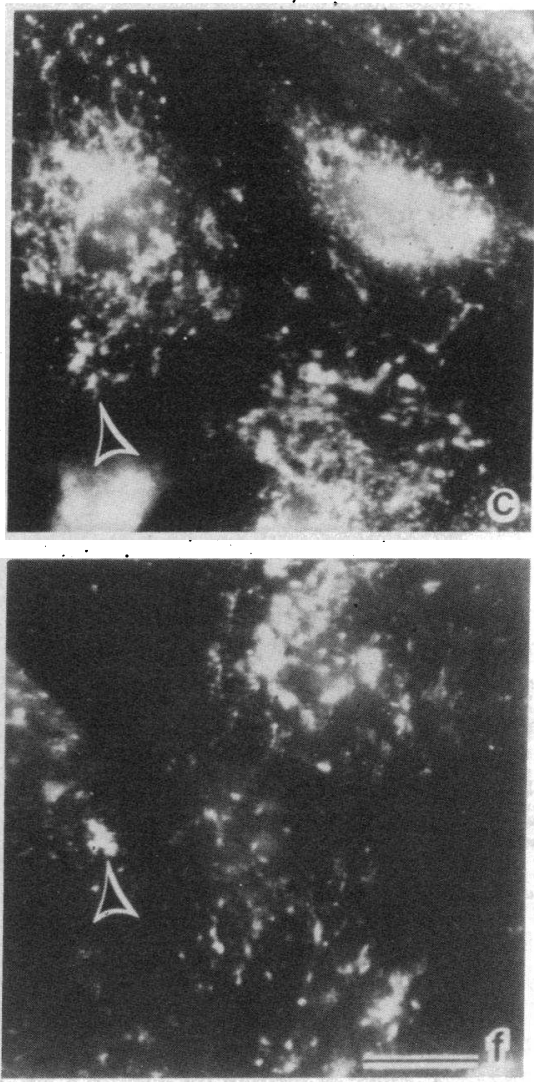

e) Cells $10 \mathrm{~min}$ after the addition of fibrinogen (no clot present). ( $c$ and $f$ ) Cells after $3 \mathrm{~h}$, at which time a fibrin clot had formed. The formation of a clot was associated with a marked decrease in the number of stainable Weibel-Palade bodies (arrows) and appearance of extracellular patches of bright staining typical of $\mathrm{vWf}$ release (arrowheads). Bar, $20 \mu \mathrm{m}$.

purified vWf, as determined by scanning of the autoradiographs. Incubation of fibrin clots with the A23187 releasate in the absence of cells for $10 \mathrm{~min}$ did not produce fragmentation of the vWf subunit (not shown).

The clot liquor failed to stimulate $v W f$ releáse (Table II), indicating that fibrinopeptides $A$ and $B$, which are cleaved by thrombin during fibrin formation, were ineffective stimulants. Tissue plasminogen activator $(100 \mathrm{ng} / \mathrm{ml})$ and activated Factor XIII $(1 \mathrm{U} / \mathrm{ml})$ did not stimulate release above background (not shown). In addition, washed red cells did not cause release (Table II), suggesting that interaction with a foreign surface is not a sufficient release stimulus. Addition to endothelial cells of fresh, unanticoagulated whole blood $(2 \mathrm{ml} / \mathrm{dish})$ resulted in a rapid formation of a clot within 10 min causing release of $\mathrm{vWf}$ (Table II) with no major change in endothelial cell shape or adherence. Reptilase, an enzyme derived from the venom of Bothrops atrox, cleaves only fibrinopeptide $A$ from fibrinogen resulting in a structurally different clot with minimal Factor XIII cross-linking (Fig. 6). Clots formed with reptilase failed to stimulate release from the Weibel-Palade bodies (Table II), indicating that the specific fibrin structure resulting from thrombin action was necessary for stimulation. 
Control
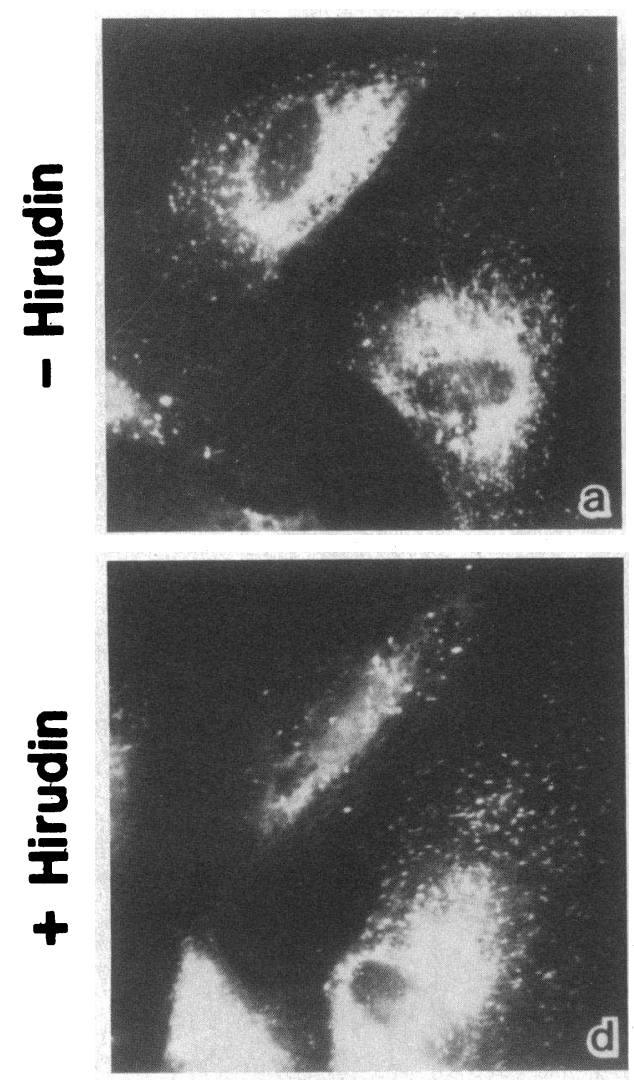

Figure 3. Effect of hirudin on thrombin and clot-stimulated release of vWf from endothelial cells. Human umbilical vein endothelial cells were left unstimulated ( $a$ and $d$ ) or were exposed to either preformed fibrin clots $(b$ and $e$ ), or $0.1 \mathrm{U} / \mathrm{ml}$ thrombin $(c$ and $f$ ). Fibrin clots were prepared using $5 \times 10^{-3} \mathrm{U} / \mathrm{ml}$ thrombin and washed for $18 \mathrm{~h}$ in McCoy's medium $(b)$ or McCoy's medium containing $0.25 \mathrm{U} / \mathrm{ml}$ hirudin $(e)$. Experiments were performed in the absence $(a-c)$ or presence

\section{Discussion}

Exposure of endothelial cells to fibrin resulted in rapid secretion of vWf into the medium, association of vWf with the endothelial cell surface, and disappearance of Weibel-Palade bodies from

Table I. Release of $v W f$ from Endothelial Cells in Response to Thrombin or Fibrin in the Presence or Absence of Hirudin

\begin{tabular}{lcc}
\hline & \multicolumn{2}{c}{ Released cells* } \\
\cline { 2 - 3 } Stimulus & $10 \mathrm{~min}$ & $3 \mathrm{~h}$ \\
\hline & $\%$ & $\%$ \\
None & 11 & 8 \\
Hirudin $(0.25 \mathrm{U} / \mathrm{ml})$ & 6 & 12 \\
Thrombin $(0.1 \mathrm{U} / \mathrm{ml})$ & 81 & 86 \\
Thrombin $(0.1 \mathrm{U} / \mathrm{ml})+$ hirudin $(0.25 \mathrm{U} / \mathrm{ml})$ & 5 & 14 \\
Fibrin clot $^{\ddagger}$ & 82 & 100 \\
Fibrin clot clo $^{\ddagger}$ hirudin $(0.25 \mathrm{U} / \mathrm{ml})$ & 92 & 99 \\
\hline
\end{tabular}

* All percentages represent the mean of two to eight determinations. $\ddagger 5 \times 10^{-3} \mathrm{U} / \mathrm{ml}$ thrombin used in clot formation.
Fibrin Thrombin
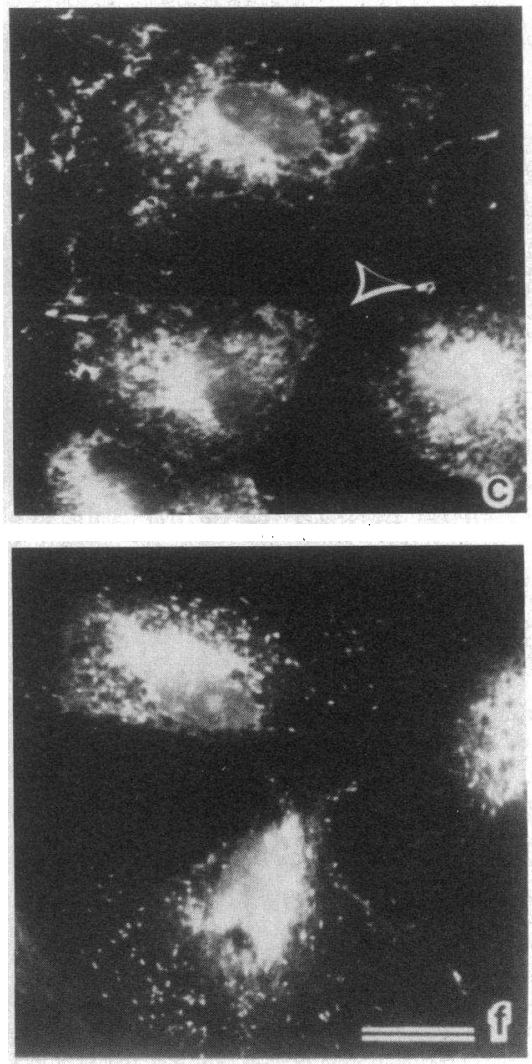

$(d-f)$ of $0.25 \mathrm{U} / \mathrm{ml}$ hirudin in the culture medium. After a 10 -min exposure to thrombin or clot, the cells were fixed, permeabilized, and stained with anti-vWf antiserum. Hirudin alone did not affect the distribution of $\mathrm{vWf}(d)$ in comparison with the control $(a)$. Thrombin stimulation resulted in bright patches of release (c, arrowheads), and was completely inhibited by the addition of hirudin $(f)$. Hirudin did not inhibit $\mathrm{vWf}$ release stimulated by fibrin clots $(e)$ Bar, $20 \mu \mathrm{m}$.

the cytoplasm. The release was stimulated by either preformed clots or in situ fibrin polymerization after addition of fibrinogen or blood to the culture medium containing trace amounts of thrombin. Secretion of $v W f$ occurred within 10 min after fibrin exposure, and there was no reappearance of Weibel-Palade bodies by $3 \mathrm{~h}$ in cells continuously exposed to fibrin. This indicates an absence of net $\mathrm{vWf}$ storage during the period of fibrin exposure due to either constant release from Weibel-Palade bodies or alteration in vWf targeting. Ineffective stimuli included washed red cells, fibrinogen, tissue plasminogen activator, activated Factor XIII, and the clot liquor containing fibrinopeptides A and B (Table II). The requirement for a particular fibrin structure in mediating release was indicated by the failure of stimulation by clots made with reptilase, an enzyme that cleaves only fibrinopeptide A (28), does not activate the cross-linking enzyme Factor XIII (29), and results in the formation of a clot of different physical properties and structure (references 28 and 29, Fig. 6). The ability of fibrin clots heated to $100^{\circ} \mathrm{C}$ to induce prompt release indicated that the necessary fibrin structure in the thrombin-formed clot was heat stable.

The vWf stored in Weibel-Palade bodies is composed of high molecular mass multimers of highly processed protein that does not contain the pro-vWf subunit in contrast to that secreted 
B

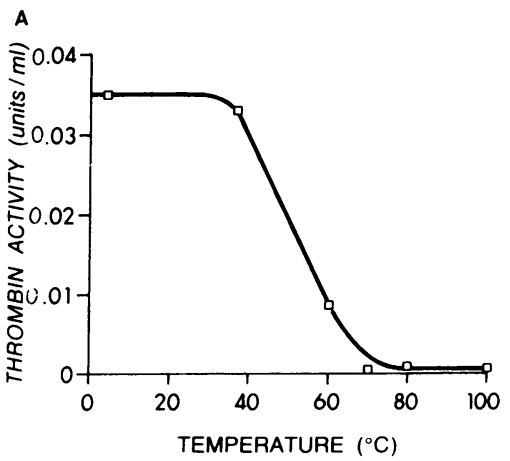

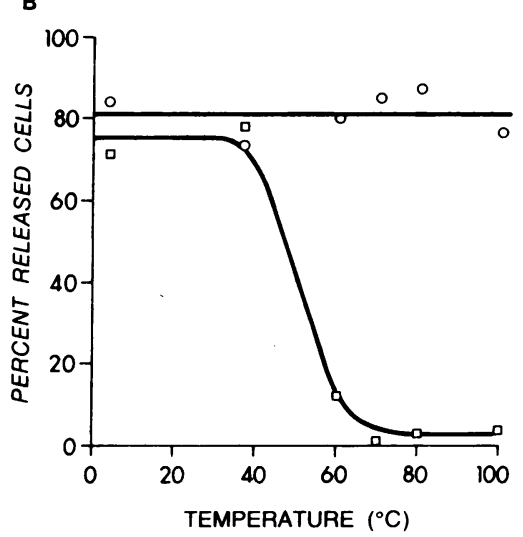

Figure 4. Effect of heating on thrombin activity and on the ability of thrombin or fibrin to induce $\mathrm{vWf}$ release from endothelial cells. $(A)$ Thrombin $(0.1 \mathrm{U} / \mathrm{ml}$ in Hanks' buffer) was incubated for $2 \mathrm{~h}$ at temperatures from $4^{\circ}$ to $100^{\circ} \mathrm{C}$ after which the solutions were equilibrated to $25^{\circ} \mathrm{C}$ and assayed for activity using a chromogenic substrate. Each point represents the average of two separate determinations. $(B)$ Fibrin clots were prepared in Hanks' buffer using a thrombin concentration of $5 \times 10^{-3} \mathrm{U} / \mathrm{ml}$. The washed clots and a solution of thrombin $(0.1 \mathrm{U} / \mathrm{ml}$ in Hanks' buffer) were both incubated for $2 \mathrm{~h}$ at temperatures from $4^{\circ}$ to $100^{\circ} \mathrm{C}$, equilibrated to $37^{\circ} \mathrm{C}$, and then placed over $80 \%$ confluent endothelial cells for $10 \mathrm{~min}$. The cells were then fixed, permeabilized, stained by immunofluorescence for $\mathrm{vWf}$, and the percentage of cells showing vWf release determined. All points represent the average of two experiments. Open squares, data points for thrombin. Open circles, data points for fibrin stimulation. constitutively (19). The $\mathrm{vWf}$ released by fibrin, similar to A23187-released vWf(19), did not contain the pro-vWf subunit (Fig. 5), indicating that it also originated from the Weibel-Palade bodies. Fibrin did not cause cell lysis because no pro-vWf subunits with immature carbohydrate that comprises one-half the cellular pool of $\mathrm{vWf}(18)$ was detected in the released protein (Fig. 5). The $M_{\mathrm{r}} 180,000$ subunit fragment seen in the fibrinreleased vWf (Fig. 3) is of similar size to a major fragment of $M_{\mathrm{r}} 176,000$ found in cryoprecipitate (22) or normal human plasma (30). It was not seen after release with A23187 (19) or after incubation of the $\mathrm{A} 23187$ releasate with fibrin, suggesting that fibrin exposure led to expression of an endothelial cell protease that partially degraded the released $\mathrm{vWf}$.

Thrombin has been shown to bind to endothelial cells (31) but its activity as secretagogue for $\mathrm{vWf}$ is related to its proteolytic activity rather than occupation of a specific receptor $(15,16)$ and is mediated by phospholipid methylation (32). We have observed a similar thrombin concentration dependence of $\mathrm{vWf}$

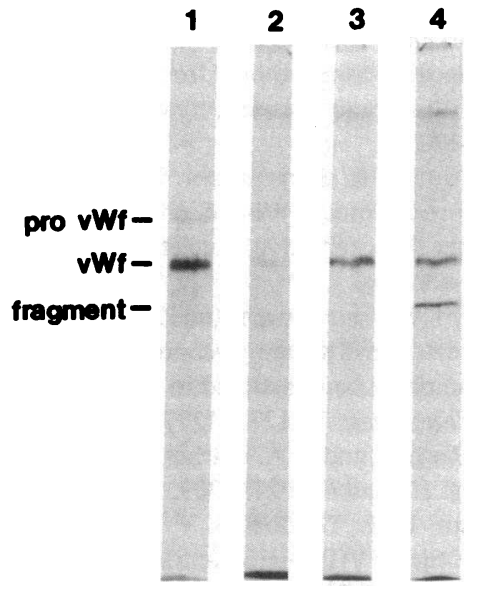

Figure 5. Comparison of the subunit composition of vWf secreted constitutively with that released by A23187 or fibrin. The figure is a composite of autoradiographs of reduced SDS 5\% polyacrylamide gels of immunopurified vWf. Endothelial cells were metabolically labeled with

$\left[{ }^{35}\right.$ S]methionine for $3 \mathrm{~d}$. Lane 1 , vWf secreted constitutively during this period. After a 6-h chase period, the cells were incubated for $10 \mathrm{~min}$ in media without stimulation (lane 2) and then treated with $10 \mu \mathrm{M}$ A23187 (lane 3) or fibrin (lane 4) for an additional $10 \mathrm{~min}$. Both A23187 and fibrin stimulated release of $\mathrm{vWf}$ from the cells and the released protein was qualitatively different from that secreted constitutively, because it did not contain the pro-vWf subunit even after longer autoradiographic exposure than is shown here. In addition, fibrin exposure resulted in the appearance of a vWf fragment of $M_{\mathrm{r}} 180,000$ (lane 4), which was not present in the $\mathrm{A} 23187$ releasate (lane 3). release to that reported by Levine and colleagues (15) (Fig. 2) and confirm that the thrombin active site is necessary for release because hirudin treatment was inhibitory (Fig. 3, Table I) and the chromogenic activity of heat-treated thrombin was closely paralleled by its ability to release vWf(Fig. 4). However, several findings indicate that the release seen after exposure to fibrin was not due to thrombin activity. First, addition of fibrinogen to endothelial cell cultures without altering thrombin concentration caused release, and the release was temporally correlated with fibrin gelation (Fig. 1). Second, rapid release occurred after exposure to preformed fibrin clots made at thrombin concentrations below that required for stimulation (Fig. 3). Third, release was not inhibited by hirudin, while hirudin inhibited release by higher concentrations of thrombin in solution (Fig. 3), and finally, heating of fibrin did not prevent release, while this completely abolished the activity of thrombin (Fig. 4). We do not exclude the possibility that thrombin at concentrations much lower than those that cause release free in solution was present in the treated clots. While this thrombin may have contributed to the release process, the primary inducer in these experiments appeared to be fibrin.

Fibrinogen has previously been shown to interact specifically with endothelial cells. Dejana et al. (33) demonstrated that fibrinogen bound to endothelial cells in a saturable and reversible

Table II. Release of $v$ Wf from Endothelial Cells in Response to Various Stimuli

\begin{tabular}{|c|c|c|}
\hline \multirow[b]{2}{*}{ Stimulus } & \multicolumn{2}{|c|}{ Released cells* } \\
\hline & $10 \mathrm{~min}$ & $3 \mathrm{~h}$ \\
\hline & $\%$ & $\%$ \\
\hline Whole blood clot ${ }^{\ddagger}$ & 74 & 93 \\
\hline Red cells ${ }^{\S}$ & 4 & 11 \\
\hline Clot liquor" & 10 & 15 \\
\hline Fibrin clot made with reptilase' & 19 & 5 \\
\hline
\end{tabular}

* All percentages represent the means of two to seven determinations.

$¥ 2 \mathrm{ml}$ of unanticoagulated blood.

'Washed red cells from $1 \mathrm{ml}$ blood suspended in $2 \mathrm{ml}$ Hanks' buffer.

" $2 \mathrm{ml}$ of fluid expressed from clots prepared with $5 \times 10^{-3} \mathrm{U} / \mathrm{ml}$ thrombin.

$1 \mathrm{U} / \mathrm{ml}$ hirudin was present during stimulation. 


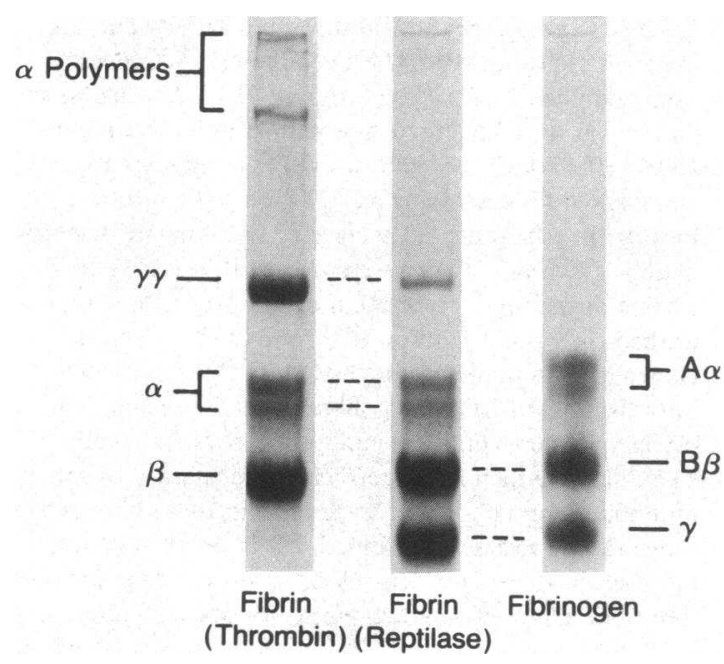

Figure 6. SDS polyacrylamide gel electrophoresis of fibrin prepared with thrombin or reptilase. Fibrinogen $(2 \mathrm{mg} / \mathrm{ml})$ was clotted with reptilase $(1.1 \mathrm{U} / \mathrm{ml})$ or thrombin $\left(5 \times 10^{-3} \mathrm{U} / \mathrm{ml}\right)$ for $16 \mathrm{~h}$ after which the fibrin was prepared for electrophoresis in $7 \%$ acrylamide gels by solubilization in SDS containing diluent with disulfide bond reduction. The polypeptide chains are labeled and show uncleaved $\mathrm{B} \beta$ chains and mostly monomeric $\gamma$ and $\alpha$ chains in the fibrin prepared with reptilase.

manner and demonstrated a partial inhibition of binding by fragment $E$ but not fragment $D$, implicating a possible binding site in the amino-terminal portion of the fibrinogen molecule (34). Dang and colleagues (35) showed that fibrinogen fragment $D$ caused disorganization of confluent endothelial monolayers with cellular retraction and projection of pseudopodia. Endothelial cells contain membrane proteins with similar electrophoretic mobility and immunological reactivity to the platelet membrane glycoproteins IIB and IIIA $(36,37)$, which function as the platelet fibrinogen receptor during aggregation $(38,39)$. In our experiments, exposure of endothelial cells to fibrinogen in the absence of clotting caused no release, indicating that occupancy of an endothelial cell membrane fibrinogen receptor was not a sufficient release stimulus. It is also unlikely that crosslinking of the fibrinogen receptors during fibrin formation caused the observed release, because fibrin formed with reptilase should also possess multiple binding sites but was ineffective (Table II).

Endothelial cells secrete several proteins involved in different aspects of the hemostatic response including $\mathrm{vWf}$, which promotes platelet adhesion and aggregation $(8,12)$, protein $S$, which potentiates the anticoagulant action of protein $C(40,41)$, and both plasminogen activators $(42,43)$ and plasminogen activator inhibitor (44), which together regulate activation of fibrinolysis. Therefore, control of endothelial cell synthesis and secretion of these proteins is of central importance in coordinating the local hemostatic response to vessel injury. The effects of thrombin on endothelial cells are multiple and include induction of both procoagulant activities, for example in increasing vWf release (15), and profibrinolytic activity such as increasing synthesis and secretion of plasminogen activator (43). However, these two disparate effects are temporally separated so that the release of $\mathrm{vWf}$ occurs rapidly $(16,19$, Fig. 3), whereas the increased secretion of plasminogen activator occurs after several hours (43), thus promoting delayed clot dissolution and removing fibrin from the endothelial cell surface.
We now show that fibrin can also modulate endothelial cell behavior by inducing the release of vWf. Endothelial cells are exposed to fibrin at sites of inflammation, vascular injury, thrombosis, and thromboembolism, and the exposure may be either brief as in formation of the hemostatic plug or prolonged as in resolution of large vascular thrombi. Kadish and colleagues (45) showed that prolonged exposure of a confluent endothelial cell monolayer to fibrin resulted in profound disruption of cellular organization with separation of the monolayer into individual migratory cells within $4 \mathrm{~h}$. Our results indicate that, in addition, exposure of endothelial cells to fibrin induces both rapid and sustained changes in vWf storage and handling by endothelial cells, with rapid release of Weibel-Palade body contents and sustained inhibition of $\mathrm{vWf}$ storage.

\section{Acknowledgments}

We acknowledge Dr. V. J. Marder for critical review of the manuscript, Dr. Kenneth Mann for helpful discussion, and Carol B. Weed for help in the preparation of the manuscript.

This work was supported by grant HL-30616 from the National Heart, Lung and Blood Institute, National Institutes of Health, Bethesda, MD and was done in part during the tenure of an Established Investigatorship from the American Heart Association (Dr. Francis) and with funds contributed by the New York State Affiliate, Inc.

\section{References}

1. Tschopp, T. B., H. J. Weiss, and H. R. Baumgartner. 1974. Decreased adhesion of platelets to subendothelium in von Willebrand's disease. J. Lab. Clin. Med. 83:296-300.

2. Sakariassen, K. S., P. A. Bolhuis, and J. J. Sixma. 1979. Human blood platelet adhesion to artery subendothelium is mediated by factor VIII-von Willebrand factor bound to the subendothelium. Nature (Lond.). 279:636-638.

3. Marguerie, G. A., E. F. Plow, and T. S. Edgington. 1979. Human platelets possess an inducible and saturable receptor specific for fibrinogen. J. Biol. Chem. 254:5357-5363.

4. Bennett, J. S., and G. Vilaire. 1979. Exposure of platelet fibrinogen receptors by ADP and epinephrine. J. Clin. Invest. 64:1393-1401.

5. Hovig, T., and H. Stormorken. 1974. Ultrastructural studies on the platelet plug formation in bleeding time wounds from normal individuals and patients with von Willebrand's disease. Acta Pathol. Microbiol. Scand. 248(Suppl.):105-122.

6. Turitto, V. T., H. J. Weiss, and H. R. Baumgartner. 1984. Platelet interaction with rabbit subendothelium in von Willebrand's disease: altered thrombus formation distinct from defective platelet adhesion. $J$. Clin. Invest. 74:1730-1741.

7. De Marco, L., A. Girolami, T. S. Zimmerman, and Z. M. Ruggeri. 1986. von Willebrand factor interaction with the glycoprotein IIb/IIIa complex. Its role in platelet function as demonstrated in patients with congenital afibrinogenemia. J. Clin. Invest. 77:1272-1277.

8. Zimmerman, T. S., Z. M. Ruggeri, and C. A. Fulcher. 1983. Factor VIII/von Willebrand factor. Prog. Hematol. 13:279-309.

9. Rand, J. H., I. I. Sussman, R. E. Gordon, S. V. Chu, and V. Solomon. 1980. Localization of factor-VIII-related antigen in human vascular subendothelium. Blood. 55:752-756.

10. Koutts, J., P. N. Walsh, E. F. Plow, J. W. Fenton, II, B. N. Bouma, and T. S. Zimmerman. 1978. Active release of human platelet factor VIII-related antigen by adenosine diphosphate, collagen, and thrombin. J. Clin. Invest. 62:1255-1263.

11. Zucker, M. B., M. J. Broekman, and K. L. Kaplan. 1979. Factor VIII-related antigen in human blood platelets. Localization and release by thrombin and collagen. J. Lab. Clin. Med. 94:675-682.

12. Jaffe, E. A., L. W. Hoyer, and R. L. Nachman. 1973. Synthesis 
of antihemophilic factor antigen by cultured human endothelial cells. $J$. Clin. Invest. 52:2757-2764.

13. Wagner D. D., J. B. Olmsted, and V. J. Marder. 1982. Immunolocalization of von Willebrand protein in Weibel-Palade bodies of human endothelial cells. J. Cell Biol. 95:355-360.

14. Reinders, J. H., P. G. de Groot, M. D. Gonsalves, J. Zandbergen, C. Loesberg, and J. A. van Mourik. 1984. Isolation of a storage and secretory organelle containing von Willebrand protein from cultured human endothelial cells. Biochim. Biophys. Acta. 804:361-369.

15. Levine, J. D., J. M. Harlan, L. A. Harker, M. L. Joseph, and R. B. Counts. 1982. Thrombin-mediated release of factor VIII antigen from human umbilical vein endothelial cells in culture. Blood. 60:531534.

16. Loesberg, C., M. D. Gonsalves, J. Zandbergen, C. Willems, W. F. van Aken, H. V. Stel, J. A. van Mourik, and P. G. de Groot. 1983. The effect of calcium on the secretion of factor VIII-related antigen by cultured human endothelial cells. Biochim. Biophys. Acta. 763:160-168.

17. Mannucci, P. M., M. Aberg, I. M. Nilsson, and B. Robertson. 1975. Mechanism of plasminogen activator and factor VIII increase after vasoactive drugs. Br. J. Haematol. 30:81-93.

18. Wagner, D. D., and V. J. Marder. 1984. Biosynthesis of von Willebrand protein by human endothelial cells: processing steps and their intracellular localization. J. Cell Biol. 99:2123-2130.

19. Sporn, L. A., V. J. Marder, and D. D. Wagner. 1986. Inducible secretion of large, biologically potent von Willebrand factor multimers. Cell. 46:185-190.

20. Ruggeri, Z. M., and T. S. Zimmerman. 1980. Variant von Willebrand's disease. Characterization of two subtypes by analysis of multimeric composition of factor VIII/von Willebrand factor in plasma and platelets. J. Clin. Invest. 65:1318-1325.

21. Gimbrone, M. A., Jr., R. S. Cotran, and J. Folkman. 1974. Human vascular endothelial cells in culture. Growth and DNA synthesis. J. Cell Biol. 60:673-684.

22. Martin, S. E., V. J. Marder, C. W. Francis, and G. H. Barlow. 1981. Structural studies on the functional heterogeneity of von Willebrand protein polymers. Blood. 57:313-323.

23. Marder, V. J., and N. R. Shulman. 1969. High molecular weight derivatives of human fibrinogen produced by plasmin. I. Physicochemical and immunological characterization. J. Biol. Chem. 244:2111-2119.

24. Claeson, G., L. Aurell, G. Karlsson, and P. Friberger. 1977. Substrate structure and activity relationship. In New Methods for Analysis of Coagulation using Chromogenic Substrates. I. Witt, editor. Walter de Gruyter, Berlin. 37-54.

25. Laemmli, U. K. 1970. Cleavage of structural proteins during the assembly of the head of bacteriophage T4. Nature (Lond.). 227:680-685.

26. Weber, K., and M. Osborn. 1969. The reliability of molecular weight determinations by dodecyl sulfate-polyacrylamide gel electrophoresis. J. Biol. Chem. 244:4406-4412.

27. Fairbanks, G., T. L. Steck, and D. F. H. Wallach. 1971. Electrophoretic analysis of the major polypeptides of the human erythrocyte membrane. Biochemistry. 10:2606-2617.

28. Laurent, T. C., and B. Blomback. 1958. On the significance of the release of two different peptides from fibrinogen during clotting. Acta. Chem. Scand. 12:1875-1977.

29. Kwaan, H. C., and G. H. Barlow. 1971. The mechanism of action of Arvin and Reptilase. Thromb. Diath. Haemorrh. 47(Suppl.):361-369.
30. Zimmerman, T. S., J. A. Dent, Z. M. Ruggeri, and L. H. Nannini. 1986. Subunit composition of plasma von Willebrand factor. Cleavage is present in normal individuals, increased in IIA and IIB von Willebrand disease, but minimal in variants with aberrant structure of individual oligomers (Types IIC, IID, and IIE). J. Clin. Invest. 77:947-951.

31. Awbrey, B. J., J. C. Hoak, and W. G. Owen. 1979. Binding of human thrombin to cultured human endothelial cells. J. Biol. Chem. 254:4092-4095.

32. de Groot, P. G., M. D. Gonsalves, C. Loesberg, M. F. van BuulWortelboer, W. G. van Aken, and J. A. van Mourik. 1984. Thrombininduced release of von Willebrand factor from endothelial cells is mediated by phospholipid methylation. Prostacyclin synthesis is independent of phospholipid methylation. J. Biol. Chem. 259:13329-13333.

33. Dejana, E., L. R. Languino, N. Polentarutti, G. Balconi, J. J. Ryckewaert, M. J. Larrieu, M. B. Donati, A. Mantovani, and G. Marguerie. 1985. Interaction between fibrinogen and cultured endothelial cells. Induction of migration and specific binding. J. Clin. Invest. 75:1118.

34. Dejana, E., M. Vergara-Dauden, G. Balconi, A. Pietra, G. Cherel, M. B. Donati, M. J. Larrieu, and G. Marguerie. 1984. Specific binding of human fibrinogen to cultured human fibroblasts. Evidence for the involvement of the E domain. Eur. J. Biochem. 139:657-662.

35. Dang, C. V., W. R. Bell, D. Kaiser, and A. Wong. 1984. Disorganization of cultured vascular endothelial cell monolayers by fibrinogen fragment D. Science (Wash. DC). 227:1487-1490.

36. Thiagarajan, P., S. S. Shapiro, E. Levine, L. DeMarco, and A. Yalcin. 1985. A monoclonal antibody to human platelet glycoprotein IIIa detects a related protein in cultured human endothelial cells. J. Clin. Invest. 75:896-901.

37. Fitzgerald, L. A., I. F. Charo, and D. R. Phillips. 1985. Human and bovine endothelial cells synthesize membrane proteins similar to human platelet glycoproteins IIb and IIIa. J. Biol. Chem. 260:1089310896.

38. Nachman, R. L., and L. L. K. Leung. 1982. Complex formation of platelet membrane glycoproteins IIb and IIIa with fibrinogen. J. Clin. Invest. 69:263-269.

39. Bennett, J. S., G. Vilaire, and D. B. Cines. 1982. Identification of the fibrinogen receptor on human platelets by photoaffinity labeling. J. Biol. Chem. 257:8049-8054.

40. Stern, D., J. Brett, K. Harris, and P. Nawroth. 1986. Participation of endothelial cells in the Protein C-Protein S anticoagulant pathway: the synthesis and release of Protein S. J. Cell Biol. 102:1971-1978.

41. Fair, D. S., R. A. Marlar, and E. G. Levin. 1986. Human endothelial cells synthesize protein S. Blood 67:1168-1171.

42. Levin, E. G. 1983. Latent tissue plasminogen activator produced by human endothelial cells in culture: evidence for an enzyme inhibitor complex. Proc. Natl. Acad. Sci. USA. 80:6804-6808.

43. Levin, E. G., U. Marzec, J. Anderson, and L. A. Harker. 1984. Thrombin stimulates tissue plasminogen activator release from cultured human endothelial cells. J. Clin. Invest. 74:1988-1995.

44. Dosne, A. M., E. Dupuy, and E. Bodevin. 1978. Production of a fibrinolytic inhibitor by cultured endothelial cells derived from human umbilical vein. Thromb. Res. 12:377-387.

45. Kadish, J. L., C. E. Butterfield, and J. Folkman. 1979. The effect of fibrin on cultured vascular endothelial cells. Tissue \& Cell. 11:99108. 